\title{
Solidarity and Spectatorship
}

Solidarité et spectateurs

\section{Lilie Chouliaraki}

\section{(2) OpenEdition}

\section{Journals}

\section{Electronic version}

URL: http://journals.openedition.org/questionsdecommunication/10816

DOI: 10.4000/questionsdecommunication.10816

ISSN: 2259-8901

\section{Publisher}

Presses universitaires de Lorraine

\section{Printed version}

Date of publication: 31 December 2016

Number of pages: $359-372$

ISBN: 978-2-8143-0313-3

ISSN: 1633-5961

\section{Electronic reference}

Lilie Chouliaraki, « Solidarity and Spectatorship », Questions de communication [Online], 30 | 2016

Online since 31 December 2018, connection on 04 January 2020. URL : http://

journals.openedition.org/questionsdecommunication/10816; DOI : 10.4000/

questionsdecommunication.10816 


\author{
LILIE CHOULIARAKI \\ Department of Media and Communications \\ London School of Economics and Political Science \\ UK-WC2A 2AE \\ L.Chouliaraki@|se.ac.uk
}

\title{
SOLIDARITY AND SPECTATORSHIP
}

\begin{abstract}
This paper explains a change in the communicative structure of solidarity by introducing its three key dimensions: the institutional, where the author discusses the implications of the radical expansion and concomitant instrumentalisation of the aid and development field; the political, where she addresses the end of grand narratives and the ensuing rise of individualist morality as a motivation for action; and the technological, where she shows how the new media have facilitated an unprecedented explosion of public selfexpression, thereby also changing the premises upon which solidarity is communicated. It is only in the light of these three dimensions, she argues, that we can begin to make sense of the shift from the objectivity of the theatre to the new emotionality of the mirror as a paradigmatic shift in the very meaning of solidarity.
\end{abstract}

Keywords. - solidarity, spectatorship, ironic spectator, instrumentalisation of humanitarianism, solidarity without grand narratives, technologisation of communication, theatricality of humanitarianism

\section{Lilie Chouliaraki, Solidarité et spectateurs}

Résumé. - L'article explique un changement dans la structure communicationnelle de solidarité en introduisant ses trois dimensions clés : le cadre institutionnel, au sein duquel l'auteure examine les implications de l'expansion et de l'instrumentalisation concomitante du domaine de l'aide et du développement; le cadre politique, où elle aborde la fin des grands récits et la hausse consécutive de la morale individualiste en tant que motivation pour l'action; le cadre technologique, où elle montre comment les nouveaux médias ont engendré une explosion sans précédent de l'auto-expression publique, modifiant les prémisses selon lesquelles la solidarité est communiquée. L'auteure montre que c'est seulement à la lumière de ces trois dimensions, que nous pouvons commencer à comprendre le passage de l'objectivité de la théâtralité traditionnelle à la nouvelle affectivité du miroir en tant que changement paradigmatique qui affecte le sens même de la solidarité.

Mots clés. - solidarité, spectateurs, spectateur ironique, instrumentalisation de l'humanitarisme, solidarité sans grands récits, technologisation de la communication, théâtralisation de l'humanitarisme 
"Get involved. Feeling inspired? ActionAid's supporters experience incredible feelings of happiness, warmth and pride all the time. There's no limit to the scale of amazing feelings you can get by getting involved. To discover what your feeling might be, take the ActionAid interactive quiz today"'.

( G Find your Feeling: How could Action Aid make you feel?" was a thirty-second quiz that invited us to explore what our "true feeling" towards this major humanitarian brand might be, by clicking on a number of questions: which picture moves us most, for instance? The child "next door" happily swinging away? A group of protesters in Latin America or a couple of women hugging and smiling at the camera? Depending on our choice of emotions towards these distant others, we were offered a certain self-description: we might be "warm and fluffy" or "inspired and excited", and, having been in touch with our emotions, we were then invited to "click on the link" and "find out more about Action Aid".

It is the relationship between "how I feel" and "what I can do" about distant others, so clearly thrown into relief in the Action Aid appeal, that concerns me in this article $^{2}$. There is no doubt that emotion has always played a central role in the communication of solidarity, yet, I argue, there is something distinct about the ways in which the self figures in contemporary humanitarianism. This is obvious when we consider earlier, Red Cross appeals, for instance, where the question of "what I can do" is raised through shocking images of emaciated children or Amnesty International ones, where the question is answered through a call to personalised letter-writing for the liberation of prisoners of conscience. Neither of these two examples returns the imperative to act on vulnerable strangers to ourselves, asking us to get in touch with our feelings in order to express our solidarity with them.

Taking my point of departure in this new emotionality, I explore the factors through which the communication of solidarity has changed in the course of the past four decades. A crucial period for humanitarianism, the 19702010 time span is characterised by three major, seemingly unconnected but ultimately intersecting, transformations: the instrumentalisation of the aid and development field; the retreat of the "grand narratives" of solidarity; and the increasing technologisation of communication. Whilst each transformation has been extensively explored in its own right, the co-articulation of the three and, importantly, the implications of this co-articulation for the changing meaning of solidarity have remained relatively untouched.

In drawing attention to the new emotionality of the "Find your Feeling" appeal, then, what I propose is that the meaning of solidarity today should be approached as simultaneously defined, or over-determined, by the branding strategies of Action Aid, by a generalised reluctance to accept "common humanity" as the motivation for our actions and by the interactive possibilities of online media. It is, I argue, only when we examine solidarity as a problem of communication, that is as a moral claim seeking

\footnotetext{
I "Find your Feeling" appeal on www.allaboutyou.com (presently: www.prima.co.uk), accessed 29 December 201।; quiz not available anymore.

2 An extensive version of this article was published in E. Chouliaraki (2012).
} 
to reconcile the competing demands of market, politics and the media, that we can better understand how the spectacle of suffering is subtly but surely turning the West into a specific kind of public actor - the ironic spectator of vulnerable others.

Irony refers to a disposition of detached knowingness, a self-conscious suspicion vis-à-vis all claims to truth, which comes from acknowledging that there is always a disjunction between what is said and what exists - that there are no longer "grand narratives" to hold the two together (Rorty, 1989). Whilst irony is often translated into "post-modern" postures of cool cynicism that reject moral attachment in favour of playful agnosticism, the spectacle of vulnerable others, I argue, complicates this posture in that, by virtue of confronting us with their suffering, it continues to raise the question of "what to do" - it continues to call upon us as moral actors. The ironic spectator is, in this sense, an impure or ambivalent figure that stands, at once, sceptical towards any moral appeal to solidary action and, yet, open to doing something about those who suffer.

In following the mutations of these communicative practices across time, the story of this article is essentially a story of how changes in the aesthetics of humanitarian communication are also changes in the ethics of solidarity. It is a story about how the move from an objective representation of suffering, as something separate from us that invites us to contemplate the condition of distant others, towards a subjective representation of suffering, as something inseparable from our own "truths" that invites contemplation on our own condition; it is also a move from an ethics of pity to an ethics of irony. This is an epistemic shift ${ }^{3}$ in the communication of solidarity, I contend, in that it signals the retreat of other-oriented morality, where doing good to others is about our common humanity and asks nothing back, and the emergence of self-oriented morality, where doing good to others is about "how I feel" and must, therefore, be rewarded by minor gratifications to the self the new emotionality of the quiz, the confessions of our favourite celebrity, the thrill of the rock concert and twitter journalism being only some of its manifestations.

Whilst all ethics of solidarity involve an element of "egoistic altruism", ironic solidarity differs from other versions in that it explicitly situates the pleasures of the self at the heart of moral action, thereby rendering solidarity a contingent ethic that no longer aspires to a reflexive engagement with the political conditions of human vulnerability. The decline of grand narratives has undoubtedly contributed to the rise of the ironic disposition, but, as I show below, this contingent ethics of solidarity has a more complex history that forces us to examine all three dimensions of its emergence - not only the political, but also the professional and the technological. At the heart of these aesthetic and ethical transformations, I conclude, lies a

\footnotetext{
${ }^{3}$ I here use epistemic shift and paradigm shift interchangeably to emphasise the emergence of a new rationality and practice of solidarity that drastically differs from previous ones. Such emergence, however, does not involve a revolutionary replacement of the old by the new but is instead an incremental and dispersed process, where irony co-exists with pity (for a discussion of the terms epistemic and paradigmatic shift, see Best, Kellner, 1997: x-xii ).
} 
fundamental mutation in the communicative structure of humanitarianism. This is the retreat of the theatrical structure of solidarity, where the encounter between Western spectator and vulnerable other takes place as an ethical and political event, in favour of a mirror structure, where this encounter is reduced to an often narcissistic self-reflection that involves people like "us".

Let me now sketch out this change in the communicative structure of solidarity by introducing each of the three key dimensions of its communication: the institutional, where I discuss the implications of the radical expansion and concomitant instrumentalisation of the aid and development field; the political, where I address the end of grand narratives and the ensuing rise of individualist morality as a motivation for action; and the technological, where I show how the new media have facilitated an unprecedented explosion of public self-expression, thereby also changing the premises upon which solidarity is communicated. It is, as I have said, only in the light of these three dimensions that we can begin to make sense of the shift from the objectivity of the theatre to the new emotionality of the mirror as a paradigmatic shift in the very meaning of solidarity.

\section{The instrumentalisation of humanitarianism}

The "Find your Feeling" appeal is informed by an emphasis on "inspiration" that, as Richard Turner, Action Aid's ex-Head of Fundraising, put it, focuses on making people "feel great if they give, but don't make them feel rotten if they don't" Leaving the needs-based iconography of poverty behind for inducing negative feelings of guilt, the inspiration-based approach is about inducing positive, warm feelings and, in so doing, aims at motivating longer-term support for the organisation's cause: "we'd like to think", as Turner continues, "that the kind of supporters we attract are likely to give to us for longer and give more than if we'd increased our response rate with hard-hitting, more needs-based advertising".

Reflecting a general tendency in the aid and development field, this is the language of corporate communication that, instead of traditional strategies of dissemination, prioritises the strategy of branding: the cultivation of a deep emotional attachment to a particular commodity, the NGO brand, with a view to guaranteeing customer loyalty to this brand.

Humanitarianism has, of course, never been antithetical to the market and has, in fact, been theorised as a quintessentially liberal idea born out of capitalism, for instance as the benign face of the expansion of labour markets beyond the West (Friedman, 2003). Yet, the contemporary articulation of humanitarianism with the market is a rather recent development that reflects a shift within capitalism from, what Luc Boltanski and Ève Chiapello (2005) call, a classical liberal to a

\footnotetext{
${ }^{4}$ Access: www.professionalfundraising.co.uk (October 2009).
} 
neo-liberal conception of public morality. In the light of this shift, we may argue that whereas modern humanitarianism was grounded on the crucial separation between a public logic of economic utilitarianism, applicable in the sphere of commodity exchange, and a private logic of sentimental obligation towards vulnerable others, applicable in the sphere of individual altruism and increasingly in institutionalised philanthropy, late modern humanitarianism, what I here theorise as post-humanitarianism, increasingly blurs the boundary between the two. In so doing, it manages both to turn the ever-expanding realm of economic exchange into a realm of private emotion and self-expression and, in a dialectical move, to simultaneously commodify private emotion and philanthropic obligation.

Starting in the 1980s and gaining full momentum in the early 1990s, two developments have brought about this shift towards, what Pheng Cheah (2006) calls, the instrumentalisation of the aid and development field - that is, the subordination of the other-oriented aims to save lives and change societies to the self-oriented imperative of profitable performance in the humanitarian sector itself.These are the marketisation of humanitarian practice and the production of administrative knowledge in the discipline of Development Studies.

The marketisation of humanitarian practice is a consequence of the explosion of International Organisations (IOS) and International NGOS (INGOS), in the aid and development sector. Aid agencies, for instance, expanded their operations by $150 \%$ in the 1985-95 decade whereas, in the USA alone, their numbers rose by a hundred in the 1980-1990 decade (from 167 to 267) and almost doubled

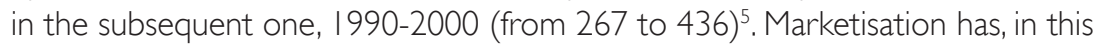
sense, emerged from these organisations' strong competition for survival, in a sector that has not only become more densely populated ${ }^{6}$ but has also come to depend primarily on project-based funding by transnational intermediaries and state donors. In the 1990-2000 decade, to give an example, funding levels rose nearly threefold, from $\$ 2$, I million to $\$ 5,9$ million, reaching more than $\$ 10$ million by $2005-2006$, whilst the distribution of these funds has increasingly shifted to depend on bilateral aid and state budgets' earmarking, thereby rendering strong state interests a key criterion for INGO fund-raising (Smillie, Minear, 2004: 8- 10 , 195; Barnett, 2005: 723-740; Barnett, Weiss, 2009: 33-35).

Even though the proliferation of humanitarian agencies has been hailed as contributing to the cosmopolitan ethos of global civil society, in that INGOS "breed new ideas, advocate, protest, and mobilize public support"', as Jessica T. Mathews's (1997: 52-53) argues, and, in the process, further "shape, implement, monitor, and enforce national and international commitments", we can clearly see that such proliferation entails a major risk. Insofar as it takes place within an economy of scarcity, where many

\footnotetext{
${ }^{5}$ See R; M. McCleary and R. J. Barro (2007) and M. Barnett and T. G. Weiss (2008) for these numbers and for discussions on the significance of this increase in the humanitarian sector.

${ }^{6}$ See A. S. Natsios (1995), P. J. Simmons (1998), and A. Cooley and J. Ron (2002) for the density argument in the sector.
} 
agencies bid for limited funding, the competition for resources inevitably tends to foster compliance with the rules of the Western donor market rather than with real priorities in the global South. Indeed, despite the expansion of the field and the provision of "more aid than ever before", as Michael Barnett and Thomas G. Weiss (2008: 34) claim, "the bulk of resources (are) controlled by a few donor countries that (are) more inclined to impose conditions and direct aid towards their priorities" so that, they conclude, "the least fortunate are getting the least of attention".

Despite, therefore, its benign objectives of maximising efficiency and increasing accountability to donors, the financial regime of the aid and development field ultimately legitimises a neo-liberal logic of governance that turns the cosmopolitan aspirations of humanitarianism into the corporate aspirations of the West and, in so doing, not only fails to serve the ideal of global civil society but bears harmful effects on vulnerable others.

If the instrumentalisation of humanitarianism is enacted through institutional practices on the ground, it is primarily legitimised through the scientific knowledge produced in the field of Development Studies. Born in the 1960s, as a response to the need to study the processes of de-colonisation and the evolution of the new states, Development Studies has always been marked by a key tension between normative theory, showing how ideal societies or states would look like, and best practice, making concrete policy recommendations that are applicable in the here-and-now (Schuurman, 2009). Even though this has historically been a productive tension that propelled critical research in the field, there has recently been, according to theorists, a definitive tip in the balance towards policy rather than normative theory (Biel, 2000; Kothari, 2005).

This means that Development Studies is today largely abandoning the critical perspectives of political economy, which thematised inequality as a systemic cause of under-development and linked inequality to non-economic issues - thus further connecting Development Studies to the disciplines of Politics, Sociology or History and Anthropology. Instead, what today dominates the field is what Ben Fine (2009) calls, "new development economics": the neo-liberal economics of the (post)Washington Consensus, which favours micro-economic, rather than macro- or structural economic, approaches to development, and methodological positivist, rather than critical reflexive, research designs.

What this discussion suggests is that, whilst substantial critical work on the instrumentalisation of both the practice and knowledge production of humanitarianism already exists, little that has been said on the impact of instrumentalisation on the communication of solidarity itself. And yet, as we saw, the shift from advocacy-based communication strategies to outsourced campaigns designed by advertising agencies, and the concomitant turn towards "consumer loyalty", " product branding" or "clientdriven inspirational campaigns" are a major part of this instrumentalisation that demands urgent critical scrutiny. Let me now turn from the institutional to the political dimension of humanitarianism in order to discuss how the meaning of solidarity itself has been changing, as a result of the post-Cold War collapse of ideologies. 


\section{Solidarity without grand narratives}

The new emotionality of humanitarian appeals is not simply due to the new instrumentalism of advocacy communication. Rather, it also has its roots in a fundamental change in the political culture of solidarity, after the end of the Cold War. Indeed, the idea of solidarity has a long and complex history (Rorty, 1989; Boltanski, 1999; Eagleton, 2009) and it is worth looking back to work out how it has been mutating in time. In its contemporary secular form solidarity dates as far back as the $18^{\text {th }}$ century and the rise of the "culture of sympathy". This was the time when the rise of modern capitalism generated a new moral discourse on the inherent goodness of human nature and on the importance of treating distant others not as enemies but as "cordial strangers" (Hyde, 1999; Hutchinson, 1996). The founding father of the economic liberalism of modernity, Adam Smith, is an instrumental figure in this discourse in that he both celebrated benevolence towards vulnerable others as a fundamental moral property of the human psyche, in his Theory of Moral Sentiments (1759), and advocated the regulation of society by the amoral "invisible hand" of commercial activity, in his Wealth of Nations ( I778; and see Shapiro 2002 for the "Smith effect" upon Western modernity).

It is, I argue, this instability between humanity and inhumanity, between benevolence and violence, that has propelled the historical variations of the meaning of solidarity in the course of modernity. Two of these variations are relevant to my discussion on humanitarianism: solidarity as salvation, or the humanitarian solidarity of the Dunantean project, and solidarity as revolution, or the political solidarity of Marxian militantism. Whereas the former is associated with humanitarianism "proper", in that it was born as a moral response to the atrocities of war and aspired to save lives and comfort suffering humanity, the latter is associated with a social critique of the conditions of suffering and aspired to change the social relations of economic exploitation that made suffering possible, in the first place.

Even though both variations share a reference to the benevolent humanism of the "culture of sympathy", they differ in that solidarity as salvation remains resolutely a-political, grounding humanitarianism on the principles of neutrality, impartiality and independence (Slim, 1997, 2003; Barnett, 2005), whilst solidarity as revolution is a profound radicalisation of the "culture of sympathy" that keeps the faith to human goodness but challenges the bourgeois benevolence of its capitalist roots, seeking to replace it with a new world order -one that is not regulated by self-interested markets but by the just re-distribution of resources across social groups (Sen, 1989).

Despite their profound differences, these two forms of solidarity, salvation and revolution, are nonetheless informed by similarly universal norms of morality. Humanitarian solidarity is informed by a morality of altruistic benevolence, which had both Christian and secular roots (Boltanski, 1999), whilst political solidarity is

\footnotetext{
7 See M. Poster (1975),T.Eagleton (1975, 1985) for discussions on Marxian humanism; see E. G.West (1969) for the affinity between Adam Smith's and Karl Marx's views on the political economy of alienation.
} 
informed by a morality of social justice, which relied on Marxian and anti-colonial theory (Calhoun, 2009; Moyn, 2010). Like all forms of universalism, however, neither of the two solidarities was ultimately able to avoid the accusation that its moral certainties were doing more harm than good to the societies they were applied to: "solidarity", in Gilroy's words (2006: 70), has become "suspect".

Ultimately, what these critiques of universalism towards both forms of solidarity, salvation and revolution, problematise is the traditional relationship between politics and solidarity. The former, the critique of salvation, points to the fact that there can be no pure humanitarianism, in that all choices to save lives are ultimately political choices about which suffering is worth alleviating and who is to blame for it. It is, at least partly, in response to the re-definition of the morality of salvation as ultimately a political morality, that the field has sought to instrumentalise its institutional practices through scientific methodologies and, in so doing, to sustain the claim that its practices remain neutral, beyond political interest. Rather than succeeding, however, humanitarianism is today accused of a double compromise not only of being "undertaken in a variety of circumstances that challenge its moral clarity" but, as Craig Calhoun (2008: 96) observes, also of being undertaken "in complex organisations that demand instrumental orientations to action".

In parallel to this attempt to defend the de-politicisation of the solidarity of salvation, there is a simultaneous marginalisation of the politics of justice in the solidarity of revolution. Symptomatic of the post-Cold War decline of narratives of social change, the retreat from justice has its roots in the New Left, which, already in the late 1960s, challenged its "Marxist predecessors" precisely for being "guilty [...] of inhumane behaviour in the name of the revolution and the better society that awaits humanity in the far-off, distant future" (Rifkin, 2009: 4 I 6). The significance of this position, which was further radicalised in the post-Cold War era, is not only historical, in that it produced a scathing attack of the inhumanity of the Soviet model of social justice, but, importantly, intellectual, in that it replaced the Marxian critique of class injustice with a new focus on the human condition - what Luc Boltanski and Ève Chiapello (2005) call, a "critique of authenticity".

Fully resonating with, albeit not restricted to, the post-modernist celebration of the death of meta-narratives, this intellectual shift towards "authenticity" rather than social justice further signals a new political focus not on the suffering society as a pathology of the capitalist system but on the suffering self as a generalised pathology of all systems of power: "Loneliness, estrangement, isolation describe the vast distance between man and man today [...] We oppose the depersonalization that reduces human beings to the status of things. If anything, the brutalities of the 20th century teach us that means and ends are intimately related, that vague appeals to 'posterity' cannot justify the mutilations of the present" (Roszak, 1995: 58 cited in Rifkin, 2009: 416).

What this move from justice to authenticity suggests is that solidarity as a vision of a suffering-free society is now replaced by a humbler vision of simply managing the present, in a non-heroic pursuit of pleasures for the self. Our moral disposition 
towards vulnerable others, we may hypothesise, consequently also changes orientation from "the worldwide ideological struggle that called forth daring, courage, imagination and idealism", as Francis Fukuyama (1989: 2) had put it, towards an orientation to "economic calculation, the endless solving of technical problems [...] and the satisfaction of sophisticated consumer demands". The instrumentalisation of the solidarity of salvation, in other words, may today be combined with an equally forceful instrumentalisation of the solidarity of revolution, where self-interest and individual pleasure take precedence over the demand for justice.

Similarly to Moyn's (2010) subjects of solidarity who are treated as individual holders of rights disembedded from structures of injustice, I argue that the publics of solidarity, too, are today called to enact solidarity as an individualist project of contingent values and consumerist activisms - ironic solidarity being precisely a solidarity that, in recognising the limits of its own legitimacy and efficacy, avoids politics and rewards the self. Even though the philosophical contours of this emerging practice of solidarity has been imaginatively conceptualised in Richard Rorty's seminal treatise on irony as a condition of solidarity, as early as in 1989, the precise content of this practice, its articulation with the market and technology as well as its implications for public morality urgently needs to become the focus of critical inquiry (see Chouliaraki, 20।3).

\section{The technologisation of communication}

The question of solidarity and its historical mutations, it follows, cannot be examined separately from the communicative structure that has made this moral discourse available to us, in the first place. The "Find your Feeling" appeal, to return to our example, is interesting precisely because its structure does not resemble earlier proposals to solidarity, in at least two ways. First, it uses the interactive affordances of the internet so as to talk about distant others, yet it ultimately communicates something about "us", and second, it invites us to connect with the Action Aid website as a response to the question of "what to do", yet it avoids the question of "why we should act". It is these two features, the invitation to self-expression and the absence of normative morality, which, I suggest, define the technologisation of humanitarianism today. Let me address each of them in turn, before I reformulate anew the main concerns of my research.

The first, the invitation to self-expression, is a key feature of new media, in that digital technologies have provided the necessary infrastructure to turn media users into producers, rather than only consumers, of public communication. Whereas the Action Aid appeal capitalised on the interactive potential of online sites to generate personalised profiles of its users, other practices of humanitarian communication rely on mobile phones, blogs and convergent journalism platforms, to involve increasingly more people into the production of their messages. The technologisation of solidarity refers, in this sense, to the capacity of digital media to incorporate the 
moral imperative to act on vulnerable others within technological platforms that render solidarity a matter of twittering personal emotion, downloading the message of our favourite celebrity, web-streaming our preferred Live 8 bands, clicking on the donation link of Action Aid or clicking "like" on a Facebook wall (Fenton, 2007).

It is this capacity of the new media to engage people in unprecedented forms of public self-presentation that, according to Jeremy Rifkin (20 I0: 555-560; see also Thumim, 2009), has defined our "empathic civilisation" as simultaneously the age of a "new dramaturgical consciousness" - the consciousness of our capacity to act ourselves out in front of unknown others. Dramaturgical consciousness, becomes, in this account, paramount in the formation of cosmopolitan dispositions, precisely because the planetary connectivity of the new media have now turned the world into a new theatrum mundi - a theatre, whose moralising force lies in the fact that we do not only passively watch distant others but we can also enter their own reality as actors: "the whole world might be a stage", Jeremy Rifkin says echoing the Shakespearean metaphor," "but during the twentieth century most of the people were in the audience, whereas in the twenty-first century everyone is onstage and in front of the spotlights, thanks to YouTube, MySpace, Facebook, the blogosphere etc." (2009: 555).

Whilst the quality of cosmopolitan dispositions that the digital media are able to mobilise is fiercely debated, what interests me here is the fact that the cosmopolitanising potential of these media relies on their capacity to act both as sites of self-expression and as sites of spectatorship: "Young people today", Jeremy Rifkin (2009: 558) continues his description of the West as an empathic civilisation, "are in front of the screen or on the screen, spending much of their waking day in virtual worlds where they are scripting multiple stories, directing their own perfromances, and choreographing virtually every aspect of their lives - hoping that millions of others will log on and follow along" (emphasis added).

In blurring the boundaries between watching and acting, self-expression challenges the modern, theatrical conception of moral education that, grounded as it was on the Enlightenment idea that virtue is to be cultivated through secular institutions, depended precisely on the act of watching and presupposed a strict separation between those who act and those who observe the actors (Marshall, 1984; Gullace, 1993). This new challenge of self-expression resonates well with the Orientalist critique of the theatre, which similarly claims that the spectacle of the vulnerable other reproduces objectified perceptions of the non-West and operates as a site of Western domination: "the Orient", as EdwardW. Said (2002: 27) has argued, "seems to be, not an unlimited extension beyond the familiar European world, but rather a closed field, a theatrical stage affixed to Europe". It is, partly, in response to such theoretical critiques of humanitarian communication as a mechanism of "othering" that self-expression has emerged, thematising the self as a key dimension of its moral discourse.

At the same time, this humanitarian turn to self-expression is also a practical response to compassion fatigue, the publics' apathy to traditional iconographies of suffering. 
Demonstrating a high degree of institutional reflexivity, as AnneVestergaard (2010) argues, major INGOS are today experimenting with a new aesthetics of solidarity that, in line with market research, is driven by the preferences of public polling - as, for instance, in Action Aid: "the charity's direction", Turner says, speaking of the new emotionality of appeals, "is the result of extensive consultation with donors and focus groups" (2009) ${ }^{8}$.

Motivated by the diagnosis of compassion fatigue, this focus on the brand capitalises on the mature market of humanitarianism, so as to take our familiarity with major INGOS for granted and avoid explicit messages of solidarity that may fuel fatigue towards grand narratives - for instance, towards the solidarity of salvation through iconographies of starving babies (McLagan, 2003; Vestergaard, 20 I0). Yet, even though branding builds upon a rather confident view of Western publics as already familiar with the morality of solidarity, the engagement of these publics with specific humanitarian brands can by no means be taken for granted. This is because, as recent UK-based research shows, Western publics may accept that helping the poor is our "human obligation" but, at the same time, appear reluctant to prioritise poverty in the South over poverty at home and, in fact, provide support, albeit limited, to cuts in humanitarian aid; such results, as Spencer Henson and Johanna Lindstrom (2010:3) put it, "are, on the one hand, quite heartening. Even in times of austerity" they argue, "there are quite strong views that we have a moral obligation to help the poor in the world. On the other", they continue, "when it comes to support for spending on aid, such values appear to be undermined by domestic priorities [...] the view seems to be that when times are tough, we cannot afford to waste money and must focus on problems closer to home".

\section{Conclusion}

The historical transformations of solidarity, I have argued in this article, is a complex matter that should be approached in its institutional, political and technological dimensions. Whilst it is impossible to produce a perfect narrative that encompasses all three in equal measure, my ambition was rather to approach the communicative practices of humanitarianism as sites of articulation, where all three dimensions intersect with and overdetermine one another, in ways that variously come to define solidarity, at different points in time.

This focus on communication is of course not new. The humanitarian field has always focused on the impact of its messages on public attitudes to solidarity - for instance, in the reflexive aesthetics of inspiration-oriented rather than needs-based discourse. More often than not, however, such concerns have failed to go beyond the instrumental question of how to maximise donor funding and to address the

\footnotetext{
${ }^{8}$ See http://www.allaboutyou.com/lifestyle/live-for-the-moment-actionaid-58250 for the "Find your Feeling" appeal (accessed 29 December 201 I).
} 
real question of how the communication of solidarity may shape longer-term perceptions of the West as a moral actor. This neglect of the performative force of humanitarian communication, not only in the direct sense of acting out dispositions of solidarity but, in so doing, also in the sense of producing the publics it addresses rather than simply referring to them as pre-existing bodies of spectators, has given rise to a "persistent problem" in the field, the problem of engagement. Whilst, according to research, INGO donations have today reached an all-time high, the quality of public engagement with questions of development appears to have fallen at its lowest point ever: "the disjuncture between the two sets of data (donations/ engagement, LC)", Andrew Darnton (201 I: I3) comments, "sparks some serious questions about how long the prevailing business model for development NGOS can continue, and what the implications are for the quality of public engagement".

The humanitarian field rightly approaches the problem of engagement as a communication problem, seeking to replace the "transaction" model of communication with a "values" model and so to introduce new interpretative "frames" for its messages of solidarity (Darnton with Martin, 20l I). My view is, however, that the paradox of engagement cannot be addressed simply by shifting around the wording of messages or moving across a continuum of given values. Far from underestimating the power of words, what I have suggested in this article is that the morality of solidarity requires a more holistic understanding of humanitarian communication as a matter of convergence between instrumentalisation, de-politicisation and mediatisation, three crucial socio-historical processes that are today responsible for the historical shift from the solidarity of pity to the solidarity of irony.

\section{References}

Barnett M., 2005, "Humanitarianism transformed", Perspectives on Politics, 3(4), pp. 723-40.

Barnett M., Weiss T. G., eds, 2008, Humanitarianism in Question: Politics, Power, Ethics, Ithaca, Cornell University Press.

Best S., Kellner D., 2007, "Debord and the Postmodern Turn: New Stages of the Spectacle”, Illuminations. Access: http://www.cddc.vt.edu/illuminations/kell I 7.htm.

Biel R., 2000, The New Imperialism: Crisis and Contradictions in North-South Relations, London, Zed.

Boltanski L., 1999, Distant Suffering: Politics, Morality and the Media, Cambridge, Cambridge University Press.

Boltanski L., Chiapello E., 2005, The New Spirit of Capitalism, transl. by G. Elliott, London, Verso.

Calhoun C., 2008, "Cosmopolitanism in the modern social imaginary", Daedalus, 137(3), pp. $105-14$.

Cheah P., 2006, Inhuman Conditions: On Cosmopolitanism and Human Rights, Cambridge, Harvard University Press. 
Chouliaraki L., 2012, The Ironic Spectator: Solidarity in the Age of Post-Humanitarianism, Cambridge, Polity Press, Outstanding Book Award 20 I5, International Communication Association.

Cooley A., Ron J., 2002, "The NGO Scramble: Organizational Insecurity and the Political Economy of Transnational Action", International Security, 27(I), pp. 5-39.

Darnton A. with Martin K., 201 I , Finding Frames: New Ways to Engage the UK Public in Global Poverty, London, Bond.

Eagleton T., 1975, Myths of Power: A Marxist Study of the Brontes, London, Macmillan Press.

Eagleton T., 1985, "Capitalism, modernism and postmodernism", New Left Review, I52, pp. 60-73.

Eagleton T., 2009, Trouble with Strangers:A Study of Ethics, Chichester, Malden,Wiley-Blackwell.

Fenton N., 2007, "Contesting Global Capital, New Media, Solidarity, and the Role of a Social Imaginary", pp. 225-42, in: Carpentier N., Cammaerts B., eds, Reclaiming the Media: Communication Rights and Democratic Media Roles, London, Intellect.

Fine B., 2009, "Development as Zombieconomics in the Age of Neo-Liberalism", Third World Quarterly, 30(5), pp. 885-904.

Friedman L. J., 2003, "Philanthropy in America: Historicism and its Discontents", pp. I -21, in: Friedman L. J., McGarvie M. D., eds., Charity, Philanthropy and Civility in American History, Cambridge, Cambridge University Press.

Fukuyama F., 1989, “The End of History?”, The National Interest, 16, pp. 3- I8.

Gilroy P., 2006, Postcolonial Melancholia, New York, Columbia University Press.

Gullace G., 1993, "On the Moral Conception of the Enlightenment", The Journal of Value Inquiry, 27(3-4), pp. 39|-402.

Henson S., Lindstrom J., 2010 , Aid to Developing Countries: Where does the UK Public Stand? Results and Analysis from the UK Public Opinion Monitor, Brighton, Institute of Development Studies.

Hutchinson J. F., 1996, Champions of Charity: War and the Rise of the Red Cross, Boulder and Oxford, Westview Press.

Hyde L., 1999, The Gift: Imagination and the Erotic Life of Property, London, Vintage.

Kothari U., ed, 2005, A Radical History of Development Studies: Individuals, Institutions and Ideologies, London, Zed.

Marshall P. D., 1984, "Adam Smith and the Theatricality of Moral Sentiments", Critical Inquiry, I0(4), pp. 592-613.

Mathews J.T., 1997, "Power Shift”, Foreign Affairs, 76(I), pp. 50-66.

McCleary R. M., Barro R. J., 2007,"“U.S.-Based Private Voluntary Organizations: Religious and Secular pvos Engaged in International Relief and Development, 1939-2004", American Political Science Association Annual Conference, 30 August-2 September 2007, Chicago.

McLagan M., 2003, "Human Rights, Testimony and Transnational Publicity", S\&F Online 2(I). Access: http://sfonline.barnard.edu/ps/mclagan.htm.

Moyn S., 20 I 0, The Last Utopia: Human Rights in History, Cambridge, Massachusetts, Harvard University Press. 
Natsios A. S., 1995, "NGOS and the UN System in Complex Humanitarian Emergencies: Conflict or Cooperation?", Third World Quarterly, I6(3), pp. 405-420.

Poster M., 1975, Existential Marxism in Postwar France: From Sartre to Althusser, Princeton, Princeton University Press.

Rifkin J., 2009, The Empathic Civilization:The Race to Global Consciousness in a World in Crisis, New York, Jeremy P.Tarcher/Penguin.

Rorty R., 1989, Contingency, Irony and Solidarity, Cambridge, Cambridge University Press.

Said E.W., 2002,"Imaginative Geography and its Representations: Orientalising the Oriental", pp. I5-37, in: Essed P., Goldberg D.T., eds, Race Critical Theories: Text and Context, Malden, Blackwell.

Schuurman F., 2009, "Critical Development Theory: Moving out of the Twilight Zone", Third World Quarterly, 30(5), pp. 83।-848.

Sen A., 1989, "Development as Capabilities Expansion", Journal of Development Planning, 19, pp. 4I-58.

Shapiro M. J., 2002, Reading Adam Smith: Desire, History and Value, Oxford, Rowman \& Littlefield.

Simmons P. J., 1998, "Learning to Live with NGos”, Foreign Policy, I I2, pp. 82-96.

Slim H., 1997, "Relief Agencies and Moral Standing in War: Principles of Humanity, Neutrality, Impartiality and Solidarity", Development in Practice, 7(4), pp. 342-352.

Smillie I., Minear L., 2004, The Charity of Nations: Humanitarian Action in a Calculating World, Bloomfield, Kumarian Press.

Smith A., 1759, The Theory of Moral Sentiments, New York, Prometheus, 2000.

Smith A., 1778, Wealth of Nations, London, W. Strahan and T. Cadell.

Thumim N., 2009, "Everyone has a Story to tell. Mediation and Self-Representation in Two UK Institutions", International Journal of Cultural Studies, 12(6), pp. 617-638.

Vestergaard A., 2010 ,"Identity and appeal in the humanitarian brand", pp. I 68-84, in: Chouliaraki L., Morsing M., eds, Media, Organizations and Identity, London, Palgrave Macmillan.

West E. G., 1969, "The Political Economy of Alienation: Karl Marx and Adam Smith", Oxford Economic Papers, 2 I ( I), pp. I-23. 